1 Chancellor AM, Slattery JM, Fraser H, Swingler RJ, Holloway SM, Warlow CP. The prognosis of adult-onset motor neuron disease: a prospective study based on the Scottish Motor Neuron Disease Register. F Neurol 1993; 240:339-46.

2 Bensimon G, Lacomblez L, Meininger V, ALS/Riluzole Study Group. A controlled trial of Riluzole in amyotrophic lateral sclerosis. $N$ Engl $f$ Med 1994;330: otrophic

3 The Scottish Motor Neuron Disease Research Group. The Scottish motor neuron disease register: a prospective study of adult onset motor neuron disease in Scotland. Methodology, demography, and clinical features of incident cases in 1989. F Neurol Neurosurg Psychiatry 1992; 55:536-41.

4 Chancellor AM, Davenport RJ, Swingler RJ, Warlow CP. The Scottish Motor Neuron Disease Register: a mode for registers of uncommon diseases in Scotland. Health Bull 1994;52:342-7.
5 Chancellor AM, Swingler RJ, Fraser H, Clarke JA, Warlow CP. Utility of Scottish morbidity and mortality data for epidemiological studies of motor neuron disease. $\mathscr{f}$ Epidemiol Community Health 1993;47:116-20.

6 Neary D, Snowden JS, Mann DMA, Northen B, Goulding PJ, Macdermott N. Frontal lobe dementia and motor neuron disease. $\mathcal{F}$ Neurol Neurosurg Psychiatry 1990;53: 23-32.

7 Talbot PR, Goulding PJ, Lloyd J, Snowden JS, Neary D, Testa HJ. Inter-relation between "classic" motor neuron disease and frontotemporal dementia: neuropsychological and single photon emission computed tomography study. F Neurol Neurosurg Psychiatry 1995;58:541-7.

8 Mulder DW, Howard FM. Patient resistance and prognosis in amyotrophic lateral sclerosis. Mayo Clin Proc 1976;51 $537-41$.

9 Chaudhry V, Corse AM, Cornblath DR, et al. Multifocal motor neuropathy: response to human immune globulin. Ann Neurol 1993;33:237-42

\title{
Historical note on the therapeutic use of botulinum toxin in neurological disorders
}

In recent years the type $\mathrm{A}$ neurotoxin of Clostridium botulinum has been successfully used for the treatment of conditions caused by focal hypercontractions of skeletal muscles (such as strabismus, hemifacial spasm, focal dystonias, and spasticity) or smooth muscles (such as achalasia). ${ }^{123}$ Symptomatic therapeutic chemodenervation was pioneered by Alan B Scott. ${ }^{4}$ Surprisingly, the idea for therapeutic use of botulinum toxin was developed 160 years before Scott's report by the German physician and poet Justinus Kerner (1786-1862). Kerner published the earliest systematic descriptions on the clinical features of foodborne botulism in 1817 in the Tübinger Blätter für Naturwissenschaften und Arzneykunde (Tübinger papers for natural sciences and pharmacology). ${ }^{5}$ Subsequently, Kerner published two monographs about botulism, in 1820 and 1822. His second monograph reviewed 155 cases of poisoned patients and was entitled Das Fettgift oder die Fettsäure und ihre Wirkungen auf den thierischen Organismus, ein Beytrag zu den in verdorbenen Würsten giftig wirkenden Stoffes (The fat poison or the fatty acid and its effects on the animal organism, a contribution to the substance which acts toxically in sausages) ${ }^{6}$ Kerner considered that a toxic substance in sausages, which he called "fatty acid", was responsible for neuromuscular paralysis. One chapter was entitled Über die Fettsäure als mögliches Heilmittel (About the fatty acid as a possible therapeutic drug). In this chapter he wrote (pp 337-50):

"Die Fettsäure oder zoonische Säure, in solchen Gaben gereicht, daß ihre Wirkung auf die Sphäre des sympathischen Nervensystems hauptsächlich beschränkt bliebe, möchte in den vielen Krankheiten, die aus Aufreizung dieses Systems entstehen, von Nutzen seyn" ("The fatty acid or zoonic acid administered in such doses, that its action could be restricted to the sphere of the sympathetic nervous system only, could be of benefit in the many diseases which originate from hyperexcitation of this system"). Kerner considered St Vitus's dance a possible indication for this treatment. Later in the monograph Kerner wrote: "Was aber hier über die Fettsäure als mögliches Heilmittel geäußert wurde, gehört allerdings nur in das Reich der Hypothesen, und kann nur von dereinstigen Beobachtungen bestätigt oder widerlegt werden" ("What is said here about the fatty acid as a therapeutic drug belongs to the realm of hypotheses and may be confirmed or disproved by observations in the future"'). Fortunately, Kerner's early vision has been realised by the work of Alan B Scott and by subsequent and ongoing clinical research on the therapeutic use of botulinum toxin in neurological disorders.

$$
\begin{array}{r}
\text { FRANK J ERBGUTH } \\
\text { Department of Neurology, } \\
\text { University of Erlangen-Nuremberg, } \\
\text { Schwabachanlage 6, } \\
\text { D-91054 Erlangen, Germany }
\end{array}
$$

1 American Academy of Neurology. The clinical usefulness of botulinum toxin $\mathrm{A}$ in treating neurologic disorders. Neurology 1990;40:1332-6.

2 Jankovic J, Schwartz K, Donovan D. Botulinum toxin treatment of cranial-cervical dystonia, spasmodic dysphonia, other focal dystonias and hemifacial spasm. $f$ Neurol Neurosurg Psychiatry 1990;53:633-9.

3 Pasricha PJ, Ravich WJ, Hendrix TR, Sostre S, Jones B, Kaloo AN. Intrasphincteric botulinum toxin for the Kaloo AN. Intrasphincteric botulinum toxin for the

4 Scott AB. Botulinum toxin injection of eye muscles to correct strabismus. Trans Am Ophthalmol Soc 1981;79:
(1) 734-70.

5 Kerner J. Vergiftung durch verdorbene Würste. Tübinger Blätter für Naturwissenschaften und Arzneykunde 1817:3: $1-25$.

6 Kerner J. Das Fettgift oder die Fettsäure und ihre Wirkungen auf den thierischen Organismus, ein Beytrag zur Untersuchung des in in verdorbenen Würsten giftig wirkenden Stoffes. Stuttgart, Tübingen: Cotta, 1822. 